and deals in a logical and comprehensive way with the many uses to which these remarkable compounds have been put. As one would expect from the title, no attention is given to the host of 'growth-regulators' not related to auxins, except the few (for example, maleic hydrazide, ethylene, etc.) that are suspected of interfering with natural auxin action. The main aspects dealt with in detail are rooting, flower and fruit production, dormancy and storage, and weed-killers. A miscellany of 'incidental' uses is also included. Much fundamental physiology has, of necessity, been introduced into these chapters on practical applications, and this has led to repetitions and overlaps with sections in the first half. It is a pity that, in a book intending to bring practice into closer contact with theory, such a divorce should have been thought necessary.

The book is illustrated with a great profusion of simple graphs re-drawn from original research articles. The majority are well and aptly chosen and serve, as indeed should all scientific illustrations, to clarify the text and avoid much tedious description. Here and there, however, the author's enthusiasm gets a little out of hand, and figures of such simplicity appear that it is difficult to see what purpose they serve. Fig. 68, in which three graphs are drawn through six 'arbitrary' points, is perhaps the worst example. I find the literary style occasionally a little disconcerting; for example, the obscurity of the sentence: "Enzymology readily recognizes the inhibition of reactions by compounds of slightly different properties from those of true substrates" (p. 165).

The book ends with a guess at the future and a warning of the dangers of promoting technology at the expense of fundamental research. The warning is indeed timely, and it is to be hoped, therefore, that Prof. Leopold's book will be widely read. The format and binding are excellent. There is an extensive bibliography of some eight hundred references, the majority of which are from American journals.

L. J. Audus

\section{PREPARING ENZYMES}

\section{Methods in Enzymo!ogy}

Edited by Sidney P. Colowick and Nathan O. Kaplan. Vol. 1 : Preparation and Assay of Enzymes. Pp. xxv +835. (New York: Academic Press, Inc.; London: Academic Books, Ltd., 1955.) 18 dollars.

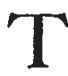

HOSE actively engaged in the field of enzymology have long felt the need for an authoritative text-book dealing with the isolation and assay of enzymes. The theory and kinetics of enzyme action have been the subject of many recent books and symposia, but a work which gives adequate practical details for the preparation of many common enzymes has not been forthcoming. Such a series is being prepared under the editorship of Drs. S. P. Colowick and N. O. Kaplan, of Johns Hopkins University, and this is the first of four volumes.

In their preface to the series, the editors state that this series should serve as a companion piece for Sumner and Myrbäck's classical work, "The Enzymes", and the present volume gives every indication of this claim being justified. There are more than a hundred and twenty articles contributed by nearly the same number of recognized experts in the enzyme field. The volume is divided into four sections, the first dealing with general preparative procedures. This is eminently readable without being too theoretical in its approach, and should serve as a useful technical basis for the investigation of new enzyme systems. The articles dealing with the variety and applicability of methods of purification are, on the whole, well written and serve to illustrate the advances that have been made in technique during recent years.

The last three sections are concerned with the specific enzymes of carbohydrate metabolism, lipid metabolism and the citric acid cycle. A method for the isolation and assay of each enzyme is given in detail, together with information, where available, concerning optimum conditions, specificity, activators, inhibitors and other data of particular use to the growing number of those who wish to use enzymes as tools in their investigations. The section on carbohydrate-metabolizing enzymes is reasonably well covered, the emphasis, however, being rather on the side of those occurring in animals and microorganisms. In particular, although plant phosphorylases and amylases are treated at length, other equally well-characterized enzymes concerned in the synthesis and breakdown of starch in higher plants are neglected. Thus some mention was to be expected of the plant branching-enzyme, $Q$-enzyme, which has been obtained in crystalline form. The section on lipid metabolism also has good general coverage, and the section dealing with enzymes of the citric acid cycle is both adequate and up to date. Compared with these two sections, the section on carbohydrate metabolism is rather large and unwieldy and might conveniently have been subdivided.

There is an occasional reference to trade products and equipment by name without further definition and with little reference to working details. In certain cases this has an adverse effect on intelligibility for the non-American reader. Nevertheless, this volume is well worth having in any laboratory where enzymes are studied or used. The system of crossreferences and the bibliography, which includes references up to 1953 , are adequate and help to ease the burden of searching through the literature.

J. R. TURVEY

\section{DAIRY SCIENCE AND PRACTICE}

\section{A Dictionary of Dairying}

By Dr. J. G. Davis. Second edition, revised and enlarged. Pp. xxviii $+1132+132$ plates. (London: Leonard Hill, Ltd., 1955.) 65s. net.

HE author of this most useful reference book, a well-known dairying consultant, has evidently been in somewhat of a quandary to find an appropriate title. "Dictionary" is a trifle misleading. Though "Encyclopædia" would probably have been too grandiloquent, the approach of the author is that of an encyclopædist rather than that of a lexicographer. He seems, too, to have been a little diffident in defining what is meant by 'dairying', a word with different connotations for different authorities dealing with the underlying science and its practical application. The precise definition which I had hoped to find is, in fact, not given in the text; on the other hand, if dairying does need an up-to-date definition, then the ground covered by this volume can reasonably be regarded as providing a sufficient one. 